\title{
Micro-econometric and Micro-Macro Linked Models: Modeling Agricultural Growth and Nutrition Linkages: Lessons from Tanzania and Malawi
}

\author{
Karl Pauw, James Thurlow, and Olivier Ecker
}

\section{Introduction}

There is widespread agreement that growth is a necessary condition for poverty reduction, although the extent to which poverty declines depends on the level and the structure of growth, and characteristics of the poor (Dollar and Kraay 2002; Ravallion and Datt 1996; Mellor 1999). Agricultural growth has been shown to be particularly effective at contributing to overall growth and reducing poverty in most developing countries, and hence this sector is often afforded priority as a growth sector in developing countries (Diao et al. 2010; Valdés and Foster 2010). This "agricultural growth hypothesis" largely serves as the justification for the Comprehensive Africa Agriculture Development Programme (CAADP), in terms of which signatories agree to allocate at least ten percent of their government budgets to the agricultural sector (for example, in the form of spending on extension services, rural infrastructure, research and development, and so on) with the aim of achieving a target of six percent annual agricultural growth.

While poverty-reduction is one objective of CAADP — and most of the CAADP country-analyses conducted by the International Food Policy Research Institute

\footnotetext{
This chapter extracts from earlier research on agricultural growth and nutrition linkages undertaken by the respective authors, as cited further below. All the authors were affiliated with the International Food Policy Research Institute (IFPRI) at the time of writing. Financial support for the research was provided by the United States Agency for International Development (USAID). Any opinions stated herein are those of the authors and do not necessarily reflect the policies or opinions of IFPRI or USAID.
}

K. Pauw $(\square)$

United Nations Food and Agriculture Organization (FAO), Addis Ababa, Ethiopia

e-mail:k.pauw@live.com

J. Thurlow $\bullet$ O. Ecker

International Food Policy Research Institute, Washington, DC, USA

C. Henning et al. (eds.), Development Policies and Policy Processes in Africa,

Advances in African Economic, Social and Political Development,

DOI 10.1007/978-3-319-60714-6_5 
(IFPRI) in recent years used this as one of the key benchmarks against which the policy was evaluated (see Diao et al. 2012) —improved food and nutrition security is arguably equally important as a development goal.

Because agriculture implies food production and because agricultural growth benefits the poor disproportionately in developing countries, there exists a perception among policymakers that the links between agricultural growth and nutrition are inevitably strong. In fact, growth in general is believed to be good for reducing malnutrition in as far as it raises household incomes, thus allowing households to access better or more nutritious food. However, some countries have seen nutrition deteriorate despite growth. ${ }^{1}$ In India, for example, rapid income growth has not translated into nutritional improvements, with stunting and wasting remaining widespread and per capita caloric availability declining (Deaton 2010). This is puzzling and hard to explain, confirming, as Timmer (2000) argued a decade before, that the mechanisms through which growth impacts on nutrition are not yet well understood analytically or quantified empirically.

The obvious conclusion is that improved nutrition is not a necessary consequence of growth-induced increases in incomes or reductions in poverty. This reflects the fact that the concept of "food and nutrition security" has several dimensions: "availability" of sufficient quantities of domestically produced or imported food; "access" to sufficient resources to acquire a nutritious diet; and "utilization" of food through adequate diet, water, sanitation and health care (Heidhues et al. 2004). In order to understand how growth impacts on nutrition it is necessary to consider how growth affects all of its dimensions.

This paper compares and summarizes findings from two recent papers, by Pauw and Thurlow (2011) and Ecker et al. (2012) in which at least two of the dimensions of food and nutrition security were modeled (i.e., availability and access). Both studies used a computable general equilibrium (CGE) model complemented with microsimulation nutrition models, and specifically consider how alternative economic growth paths ultimately impact on nutrition. The paper is structured as follows. It first compares the methods used in the respective studies and next summarizes the key results. The chapter ends by drawing general policy conclusions and outlining the way forward for these types of analyses.

\section{Methods}

\subsection{IFPRI's Standard Recursive-Dynamic CGE Model}

Both Pauw and Thurlow (2011) and Ecker et al. (2012) use IFPRI's standard recursive-dynamic computable general equilibrium (CGE) model to capture the impact of alternative sectoral growth paths on different households and regions in

\footnotetext{
${ }^{1}$ See for example Ecker et al.'s (2012) cross-country analysis.
} 
the respective countries. ${ }^{2}$ The economywide impact of growth depends largely on the inter-sectoral linkages and the way in which households are linked to different sectors via employment and consumption demand linkages. The social accounting matrix (SAM) underlying a CGE model captures these linkages.

The Tanzania model identifies 58 sectors, 26 of which are in agriculture and 10 in downstream agro-processing. Agriculture is further disaggregated across 20 sub-national regions, which captures variation in agro-ecological conditions and rural livelihood/cropping patterns. The Malawi model, in turn, includes $36 \mathrm{sec}$ tors (17 agriculture, 9 industry, and 10 services), while the agricultural sector is disaggregated across eight agroecological zones, urban areas, and small, medium, and large-scale farmers. In both models producers in each sector and region maximize profits when combining intermediate inputs with land, labor and capital. Production is specified using nested constant elasticity of substitution (CES) functions, which reflect region-specific technologies and allow for imperfect substitution between factors. In the Tanzanian model labor markets are segmented into four education groups (i.e., uneducated, primary, secondary, and tertiary), while the Malawi model includes elementary (farm) workers, unskilled workers, and skilled workers.

Economic outcomes are also affected by trade and movements in market prices. The standard CGE model assumes that producers in each region supply their output to national product markets (using a CES aggregation function), which avoids having to model inter-regional trade flows for which data is often unavailable. However, transaction costs separate regional producer and national consumer prices. International trade is captured by allowing production to shift imperfectly between domestic and foreign markets depending on the relative prices of exports and domestic products (constant elasticity of transformation function). Similarly, consumers choose between imported or domestically supplied goods depending on relative import prices (CES Armington function). Since both Tanzania and Malawi are small economies, world prices are fixed. The current account balance is maintained by a flexible real exchange rate.

Household income and expenditure patterns are important in determining how growth and relative price changes affect household incomes in the model. Both models identify farm and non-farm households in rural and urban areas, with further disaggregation by region, per capita expenditure quintiles (in the case of Tanzania) and the extent of households' land holdings (in the case of Malawi). The Tanzania model is highly detailed with 110 representative household groups, while the Malawian model includes 28 household groups. Factor incomes are distributed among households based on their factor endowments. Households save and pay taxes (at fixed rates), and the balance of income is used for consumption expenditure. The latter is based on a linear expenditure system (LES) of demand, which allows for non-unitary income elasticities and fixed marginal budget shares. Income

\footnotetext{
${ }^{2}$ For a detailed specification of this class of CGE model, see Dervis et al. (1982) and Löfgren et al. (2002).
} 
elasticities determine the responsiveness of demand for different household consumption items to income changes, and are therefore important for determining the nutrition effects of household income changes, at least in the Tanzania model, as we explain further below.

\subsection{Macro-Micro Linkages and Microsimulation Modeling}

Household poverty and nutrition are affected through both income and expenditure channels. When agricultural production expands, farm households, who derive income from land ownership and on-farm employment, are more likely to benefit from higher crop revenues, although this may be partially offset by falling producer prices and lower returns to factors. Falling prices, in turn, benefit consumers, particularly nonfarm households, but also net-consuming farm households (i.e., those producing less than they consume). We therefore expect that agricultural growth will lead to a decline in both rural and urban poverty, with the relative magnitudes of the changes depending on consumption patterns and price changes faced by either producers or consumers.

In general, however, the use of aggregate household groups in CGE models prevents a nuanced analysis of the differential poverty effects on households. Both the Tanzanian and Malawian models therefore incorporate a poverty module in which changes in prices and consumption at the representative household group level (i.e., as observed in the CGE model) are linked to corresponding member households in the underlying survey data, where changes in standard income poverty measures are computed.

The two studies, however, adopt different approaches to measuring nutrition changes. The Tanzania nutrition module developed by Pauw and Thurlow (2011) is similar to the poverty module already embedded in the CGE model. Specifically, food consumption changes (rather than changes in overall consumption values as in the poverty module) in the CGE model are linked top-down to the household data where changes in caloric availability at the household level are computed based on the nutritional characteristics of different food types. Caloric availability within each household is then compared against a measure of the daily energy requirement, which depends on a household's size and demographic structure. Households below this requirement are deemed calorie deficient or undernourished. The main "nutrition" result in Pauw and Thurlow's (2011) model is therefore changes in the calorie deficiency rate-the term nutrition is therefore used fairly loosely as it only refers to this one dimension-which is expressed either at the national level or for different household subgroups. ${ }^{3}$

\footnotetext{
${ }^{3}$ Nutritional characteristics of different food groups are derived from detailed Tanzania-specific data in Lukmanji et al. (2008). Equivalence scales in the nutrition module are from UNU, WHO, and FAO (2004). The Household Budget Survey (HBS) 2001 (NBS 2002) forms the basis of both the poverty and nutrition microsimulation modules.
} 
The UNU, WHO and FAO (2004) recommend that energy needs cannot be considered in isolation of other nutrients as "the lack of one will influence the others." Ecker and Qaim (2011) maintain that micronutrient deficiencies, especially in minerals and vitamins, are often even more widespread in developing countries than calorie deficiencies, which contributes to severe health problems in these countries. Looking beyond caloric availability is therefore critical, particularly when people suffer from multiple nutritional deficiencies as is often the case in developing countries, Malawi included. Hence, in the Malawi microsimulation model, Ecker et al. (2012) focus on a wider range of nutritional indicators.

Rather than using consumption changes observed in the CGE model directly in the nutrition model, Ecker et al. (2012) adopt the two-stage micro-econometric model developed by Ecker and Qaim (2011) to first estimate consumption changes in response to household income changes. ${ }^{4}$ In the first stage food demand elasticities are estimated assuming a quadratic almost ideal demand system (QUAIDS). In the second stage the technical coefficients from the first-stage estimation are translated into own-price, cross-price and income elasticities for different nutrients, including calories, protein, iron, zinc, and vitamins A, B3 (riboflavin), B9 (folate), B12, and C. Elasticities are estimated separately for rural and urban households across the different household quintiles. These form the basis of the microsimulation model: CGE results on income changes for different household groups are now fed into the microsimulation model where elasticities are applied to estimate new deficiency levels across the various nutrients.

From the discussion it should be apparent that the main difference between the two model frameworks lies in the specification of the microsimulation components and the way in which results from the "macro" model are linked to the "micro" level. In the Tanzania model caloric availability is calculated directly on the basis of changes in consumption quantities for different consumption items included in the CGE model. As discussed, these consumption changes are determined in an LES demand system, subject to relative price and income changes. In contrast, in the Malawi model, only changes in real household income are passed down to the micro-level. Changes in nutrient availability are calculated on the basis of income elasticities derived from a QUAIDS, a somewhat more flexible and advanced demand system, but one that stands distinct from the CGE model's LES demand system.

\footnotetext{
${ }^{4}$ The Integrated Household Survey (IHS) of 2004/05 (NSO 2005) is used as the basis of the microsimulation model (the poverty module embedded in the CGE model also uses the HIS 2004/ $05)$.
} 


\section{Country Case Studies}

\subsection{Tanzania ${ }^{5}$}

Although Sub-Saharan Africa experienced unprecedented economic growth in recent decades, this did not always translate into less poverty or improved nutrition. The Tanzanian economy is one example of a country that failed to reap the benefits of sustained rapid growth. National gross domestic product (GDP) grew at $6.6 \%$ per year during 1998-2007 (MOFEA 2008), while agricultural growth, often regarded as instrumental in lowering poverty rates in agrarian-based developing countries, averaged a respectable $4.4 \%$ over the period. Yet, between 2001 and 2007 Tanzania's poverty rate only fell from 35.7 to $33.6 \%$, while the share of the population consuming insufficient calories declined marginally from 25.0 to $23.6 \%$ (NBS 2002, 2010).

This outcome raises two questions. First, why did rapid growth not translate into more rapid reductions in poverty and malnutrition? And second, what is the contribution of agricultural growth in reducing poverty and malnutrition in Tanzania? To address these questions, an economywide model of Tanzania is linked with poverty and nutrition modules to (i) show how the current structure of growth resulted in the weak poverty and nutrition outcomes; and (ii) examine how accelerated, broad-based agricultural growth can contribute to higher overall growth and more rapid reductions in income poverty and hunger. Finally, the growth, poverty, and nutrition contributions of agricultural subsectors are examined more closely in order to identify priority sectors.

\subsubsection{Notes on the Methodological Framework}

The general equilibrium framework used for the Tanzania study incorporates both commodity demand and supply, with the latter made up of domestically produced and imported goods. This means the model is useful for considering the availability and access dimensions of food security. Prices are furthermore treated as endogenous in such models, which is important from a consumption modeling perspective. Consumption behavior is modeled on the basis of income and price elasticities estimated for each household group and commodity type. Both poverty and nutrition are affected by changes in income and relative prices. An analysis of nutrition impacts, however, requires a more in-depth look also at relative food price movements. If, for example, the price of calorie-rich maize increases and that of proteinrich meat declines such that the overall food price index does not change, the calorie

\footnotetext{
${ }^{5}$ This section was originally published as Chap. 7 of the International Food Policy Research Institute (IFPRI) book Reshaping Agriculture for Nutrition and Health, and is included with permission from IFPRI. The original publication is available online at http://dx.doi.org/10. 2499/9780896296732 (see Pauw and Thurlow 2012).
} 
Table 1 Calorie contents, calorie prices, and caloric availability in Tanzania, 2001

\begin{tabular}{|c|c|c|c|c|c|}
\hline & \multirow{2}{*}{$\begin{array}{l}\text { Average calories per } \\
\text { standard serving }^{\mathrm{a}}\end{array}$} & \multirow{2}{*}{$\begin{array}{l}\text { Mean price (TSh) } \\
\text { per } 100 \mathrm{kcal}^{\mathrm{b}}\end{array}$} & \multicolumn{3}{|c|}{$\begin{array}{l}\text { Average per capita } \\
\text { caloric availability }\end{array}$} \\
\hline & & & Poor $^{\mathrm{c}}$ & Non-poor & All \\
\hline Cereals & 294 & 6.3 & 1390 & 1885 & 1687 \\
\hline Root crops & 178 & 5.5 & 424 & 423 & 423 \\
\hline Pulses and oilseeds & 443 & 10.9 & 196 & 411 & 325 \\
\hline Horticulture & 49 & 19.8 & 106 & 240 & 186 \\
\hline $\begin{array}{l}\text { Livestock and } \\
\text { processed meat }\end{array}$ & 266 & 26.0 & 125 & 318 & 241 \\
\hline Sugar and other foods & 181 & 23.5 & 119 & 424 & 302 \\
\hline
\end{tabular}

Source: Pauw and Thurlow (2011), based on Lukmanji et al. (2008)

Notes:

${ }^{a}$ No consumption weights were applied in calculating average calories per food group

${ }^{\mathrm{b}}$ Mean price is the total expenditure divided by total calorie content per food item

${ }^{\mathrm{c}}$ Poverty line is the 40th percentile of per capita expenditure; $k c a l$ kilocalories; TSh Tanzanian shilling

deficiency rate might decline and the protein deficiency rate might increase, even though the poverty rate remains unchanged. The rich (food) commodity-household specification in the CGE model is useful in this regard, as it captures important differences in consumer spending preferences and responsiveness to income and relative price changes across household types.

To avoid the feeling of hunger poorer consumers often allocate a larger share of their income to food types with high calorie contents and lower costs per calorie. Table 1 compares the calorie content of different foods in Tanzania. It shows how the price per 100 kilocalories ( $\mathrm{kcal}$ ) varies by product, and shows average calories available from different food products for poor and nonpoor households. Livestock products have a higher average calorie content per $100 \mathrm{~g}$ serving compared to most other food types, but they also have a higher price that makes them an expensive energy source. Cereals offer a similar amount of calories per serving, but cost considerably less than livestock products.

\subsubsection{Tanzania's Recent Growth Performance}

An examination of recent production trends suggests that although the agricultural sector as a whole grew rapidly during $1998-2007$ (at $4.4 \%$ per year), growth has been volatile, while the source of this growth has been concentrated among a few crops. Rice and wheat, for example, dominate cereals production trends, and cotton, tobacco, and sugar production grew almost $10 \%$ per year. Larger-scale commercial farmers grow these well-performing crops on farms heavily concentrated in the northern and eastern periphery of the country. In contrast, yield for maize, the dominant staple food crop grown extensively by subsistence farmers, remained low 
due to primitive farming methods. Despite rice and wheat expansion and generally favorable agroecological conditions, Tanzania remains a net cereals importer because production has failed to keep pace with rising consumer demand.

Roots, such as cassava and potatoes, are also important food sources and account for almost $15 \%$ of Tanzania's harvested land. Root crops have performed well recently with more than $4 \%$ annual growth. By contrast, higher-value pulses and vegetables have stagnated, with pulses production declining by more than $4 \%$ each year. This was partly offset by expanded oilseeds production throughout the country and by fruit production in the northern and eastern regions. Non-cereal food crop production has therefore been characterized by slow growth in widely produced crops, and fast growth in regionally concentrated crops.

Some of the fastest growth rates during 2000-2007 were for export-oriented crops, such as cotton, sugarcane and tobacco. However, these crops are highly concentrated in specific regions. Cotton is mainly produced by smallholders in the western and lake regions (81.5\% of national output). Tobacco, another smallholder crop, is produced in the western and highlands regions (82.8\%). Sugarcane is mostly produced by larger-scale commercial farmers in the eastern and northern regions $(83.8 \%)$. Together these three crops generated $17.4 \%$ of total merchandise exports in 2007. Coffee and tobacco are also major export crops, but their production has declined in recent years. Growth in export agriculture has therefore been driven by the strong performance of a few regionally concentrated crops. Thus, though the aggregate agricultural sector's substantial expansion in recent years suggests broad-based agricultural growth in Tanzania, a closer examination of agricultural production data suggests the opposite.

\subsubsection{Comparing Business-as-Usual Growth to Broad-Based Agricultural Growth}

To better understand the poverty and nutritional implications of Tanzania's historical growth path, the CGE model is used to produce a baseline scenario that assumes recent production trends continue over the period 2007-2015. These results are compared to a hypothetical scenario with accelerated agricultural growth ("agriculture scenario") in which agricultural GDP growth averages 5.3\%. This scenario assumes a more broad-based agricultural growth path, with yields for crops that have performed well in the past (e.g., rice, wheat, and certain export crops) improving only marginally, while poor-performing crops (e.g., maize, pulses, and vegetables) experience larger yield gains, reflecting their greater growth potential.

The effectiveness of growth achieved under the two scenarios is measured with the aid of two types of elasticity: the poverty-growth elasticity and the caloriegrowth elasticity. The poverty-growth elasticity is defined as the percentage decline in poverty caused by a one percent increase in per capita GDP. Similarly, the calorie-growth elasticity is the percentage change in the calorie deficiency rate 
Table 2 Modeled poverty- and calorie-growth elasticities for Tanzania, 2007-2015

\begin{tabular}{|c|c|c|c|c|c|}
\hline & $\begin{array}{l}\text { Initial } \\
\text { deprivation } \\
\text { rate }(\%)\end{array}$ & $\begin{array}{l}\text { Final } \\
\text { deprivation } \\
\text { rate }(\%)\end{array}$ & $\begin{array}{l}\text { Avg. annual \% } \\
\text { change in } \\
\text { deprivation rate (a) }\end{array}$ & $\begin{array}{l}\text { Annual per } \\
\text { capita GDP } \\
\text { growth (b) }\end{array}$ & $\begin{array}{l}\text { Deprivation- } \\
\text { growth } \\
\text { elasticity (a)/(b) }\end{array}$ \\
\hline \multicolumn{6}{|c|}{ Baseline scenario } \\
\hline Poverty rate & 40.0 & 29.6 & -3.7 & 3.6 & -1.03 \\
\hline $\begin{array}{l}\text { Calorie } \\
\text { deficiency }\end{array}$ & 23.5 & 17.6 & -3.5 & 3.6 & -0.99 \\
\hline \multicolumn{6}{|c|}{ Agriculture scenario } \\
\hline Poverty rate & 40.0 & 25.7 & -5.4 & 4.1 & -1.32 \\
\hline $\begin{array}{l}\text { Calorie } \\
\text { deficiency }\end{array}$ & 23.5 & 13.8 & -4.8 & 4.1 & -1.57 \\
\hline
\end{tabular}

Source: Results from the Tanzania CGE model and poverty/nutrition modules

divided by the percentage change in per capita GDP. Table 2 reports the deprivation-growth elasticity results from the baseline and agriculture scenarios. Average annual per capita GDP grew by 3.6 and $4.1 \%$ under the two scenarios respectively, while poverty declined by 3.7 and $5.4 \%$ respectively. This suggests a poverty-growth elasticity of -1.03 in the baseline scenario. In the agriculture scenario the poverty-growth elasticity increases to -1.32 . The nutrition module, in turn, shows declines in the malnutrition rate of 3.54 and $4.84 \%$ in the two scenarios. This yields a baseline calorie-growth elasticity of -0.99 , while in the agriculture scenario the calorie-growth elasticity improves significantly to -1.57.

The results confirm that broad-based agricultural growth greatly strengthens the impact of growth on poverty. The calorie-growth elasticity also rises substantially under the broad-based agricultural growth scenario, which is a reflection of the increased production and consumption of calorie-rich maize, sorghum, millet, and pulses.

\subsubsection{Identifying Priority Sectors for Agricultural Growth}

While the previous section illustrated the benefits of broad-based agricultural growth, ascertaining whether certain agricultural subsectors are more effective than others in improving the poverty and nutritional outcomes of agricultural growth requires further modeling. Growth within different agricultural subsectors can have different impacts on development outcomes for various reasons. First, poorer households may be more intensively engaged in the production of certain crops or agricultural products. Similarly, some subsectors produce products that poorer households consume more intensively. Growth or price fluctuations in these sectors will therefore have a greater impact on poverty than growth or price fluctuations in other sectors. Second, some subsectors produce products that are particularly important for households' nutritional status, such as those that represent 
Table 3 Poverty, nutrition, and growth effects of agricultural subsector growth, 2007-2015

\begin{tabular}{l|l|l|l}
\hline & $\begin{array}{l}\text { Poverty-growth } \\
\text { elasticity }\end{array}$ & $\begin{array}{l}\text { Calorie-growth } \\
\text { elasticity }\end{array}$ & $\begin{array}{l}\text { Size and } \\
\text { linkage effects }\end{array}$ \\
\hline Maize-led growth & -1.174 & -1.477 & 0.152 \\
\hline Sorghum and millet-led growth & -1.139 & -1.348 & 0.033 \\
\hline Rice and wheat-led growth & -1.106 & -1.147 & 0.106 \\
\hline Root crops-led growth & -1.184 & -1.350 & 0.106 \\
\hline Pulses and oilseeds-led growth & -1.146 & -1.161 & 0.101 \\
\hline Horticulture-led growth & -1.126 & -1.092 & 0.186 \\
\hline Export crops-led growth & -1.097 & -1.057 & 0.098 \\
\hline Livestock-led growth & -1.084 & -0.977 & 0.204
\end{tabular}

Source: Results from the Tanzania CGE model and poverty/nutrition modules

low-cost sources of calories or are consumed intensively by nutrient-deficient households. While these elasticities are by definition growth neutral, growth itself is crucial for reducing poverty and malnutrition. Thus, a third factor concerns growth itself, and the fact that some sectors, due to their initial size in the economy, downstream production linkages (such as their production multiplier effects), or growth potential (signified by current yield gaps) can have a greater impact on overall growth. These three criteria are taken into account when identifying subsectors most effective at reducing poverty and malnutrition in Tanzania.

Comparative results are presented in Table 3. The simulated growth in each subsector achieves the same target agricultural GDP by 2015 in each simulation, thus ensuring that the poverty- and calorie-growth elasticities are directly comparable across subsectors. The three highest poverty-growth elasticities are for growth led by maize, root crops, and pulses and oilseeds. These crops are important expenditure items for households just below the poverty line and are grown more intensively by poorer farm households. In contrast, the poverty-growth elasticity for rice- and wheat-led growth is lower, mainly because these crops are grown in less poor regions of the country and, in the case of wheat, by largerscale farmers who are less likely to be poor. The calorie-growth elasticities indicate that maize, sorghum and millet, and root crops raise household caloric availability per unit of growth most effectively. Although pulses and oilseeds have high calorie contents, the poor consume these less intensively since the crops are a fairly expensive source of calories. Livestock products have the lowest elasticityin spite of the relatively high calorie content of meat products-because they are an expensive source of calories and calorie-deficient households consume them less intensively.

Production multipliers provide a useful indicator of the growth linkages of different subsectors. Multiplying each sector's production multiplier by its initial share in agricultural GDP constructs a simple index of the contribution each unit of additional growth within a sector makes to overall GDP. This index, shown in the last column of Table 2, identifies horticulture, livestock, and maize as sectors with 
the greatest potential to have a meaningful effect on national GDP in Tanzania within the 8-year timeframe of our simulation analysis.

\subsubsection{Policy Recommendations}

The analysis here suggests Tanzania's low poverty-growth elasticity results from the current structure of agricultural growth, which favors larger-scale production of rice, wheat, and traditional export crops in specific geographic locations. Accelerating agricultural growth in a wider range of subsectors than those currently leading the growth process can strengthen growth's effectiveness at reducing poverty. Faster agricultural growth would also benefit urban and rural households by increasing caloric availability and the ability to pay for food. Such nutritional improvements are best achieved by improving production of key calorie-laden food crops. The staple maize, already grown extensively by subsistence smallholders in Tanzania, has important size and growth linkages in the economy in addition to having large poverty-growth and calorie-growth elasticities. The analysis therefore identifies this sector as a priority sector for achieving growth, poverty, and nutrition objectives.

The modeling analysis by Pauw and Thurlow (2011) did not explicitly consider how increased agricultural productivity might be achieved or what the cost might be in terms of investments, extension services, or subsidies. However, studies for Tanzania and elsewhere have identified various interventions required to improve smallholders' crop yields, such as investing in rural infrastructure, researching and adopting improved seed varieties, and providing extension services. In recent years the Tanzanian government has allocated a relatively small share of its budget to agriculture. However, current development plans indicate a reprioritization of agriculture as a driver of economic growth and socioeconomic development. Pauw and Thurlow's (2011) results provide some indication of which agricultural sectors should be prioritized within this development plan in order to maximize national growth, poverty, and nutrition outcomes.

\subsection{Malawi}

While economic growth is generally acknowledged as a necessary precondition for reducing poverty, relatively little is known about how growth and nutrition are related. Therefore, questions persist regarding how to leverage economic policies so that they have a larger impact on nutrition. In recent years the Malawian government allocated a large share of its resources to the Farm Input Subsidy Program (FISP). Subsidized fertilizer and seed mainly for maize production led to rapid GDP growth during 2005-2010. It is obvious that an abundant supply of the calorie-laden staple maize is good for reducing calorie deficiency; however, it is less clear how FISP has affected micronutrient deficiencies, which are high in Malawi. This section explores diverse 
poverty and nutritional outcomes of recent maize-led growth in Malawi, drawing on the analysis by Ecker et al. (2012). Their study comprises two components: first, a cross-country analysis of the links between growth and nutrition outcomes; and second, a modeling analysis which includes case studies on Yemen and Malawi. We focus on those findings that are relevant to Malawi.

\subsubsection{Cross-Country Evidence on the Relationship Between Growth and Nutrition}

Ecker et al.'s (2012) cross-country analysis reveals that while some countries have been successful in leveraging growth for improved nutrition outcomes, others have seen nutrition deteriorate despite growth. In general, economic growth positively influences nutrition, but it is often not sufficient. During the early stages of development growth helps reduce calorie deficiency rates in particular, and, in most countries, agricultural growth plays a key role.

Calorie deficiency rates become less responsive to growth as its prevalence declines, and at this stage in the development process economic diversification into manufacturing and services is often necessary to leverage further economic growth, especially as rural-to-urban migration intensifies. Growth is generally insufficient to address all aspects of malnutrition, including child undernutrition and micronutrient deficiencies. Strategic investments and special programs are needed in sectors such as health and education.

\subsubsection{Malawi's Farm Input Subsidy Program}

The Malawian economy is agriculture-based and features limited economic diversity. Maize and tobacco are dominant subsectors, jointly contributing almost $15 \%$ to national GDP, and hence the performance of the agricultural sector and the economy as a whole is highly dependent on these sectors. Growth in the predominantly rainfed agricultural sector is volatile due to frequent droughts and floods. During 1990-2005 Malawi suffered at least three severe droughts and four major floods, with the agriculture sector contracting during 4 of these 15 years. The country has experienced at least two major food deficits since the turn of the millennium, leading to famine in 2002 and a serious food emergency in 2005. Frequent poor harvests combined with poor management of grain stocks contribute to food insecurity in Malawi.

During the 2005-2006 growing season, and in response to particularly severe food supply problems experienced in 2005, the government of Malawi initiated the Farm Input Subsidy Program (FISP), a large scale subsidy scheme that significantly reduces fertilizer and hybrid maize seed costs faced by resource-poor smallholders. The program has been lauded for its success in raising maize yields and contributing to overall economic growth, despite legitimate concerns about its fiscal sustainability (program costs have ranged from 5-16 percent of GDP since inception). Rapid maize output growth improved food security and raised caloric availability. 
However, it is less clear how FISP may have impacted on micronutrient deficiencies in iron, zinc, vitamin A, and folate, which historically have been high.

The Malawi case study in Ecker et al. (2012) assesses the ways and extent to which FISP-led growth has contributed to nutrition outcomes in the country, and also considers nutritional outcomes under future growth scenarios. In this analysis, they use an economywide ("macro") model which is linked to household and child nutrition simulation ("micro") models. The combined analytical framework thus permits analyses of the effects of policy shocks on sector-level economic growth and household incomes, and how this in turn affects nutritional status.

\subsubsection{Modeled Scenarios and Results}

Three scenarios are explored. In the first, the period of rapid maize-led agricultural growth experienced under FISP during 2005-2010 is replicated. Under this scenario national GDP growth averages $6.8 \%$, with growth in cereals driving overall economic growth (Table 4). These estimates are largely consistent with preliminary GDP growth estimates from Malawi national accounts.

Two future scenarios (2010-2020) are also modeled. The first assumes a return to long-term growth of around four percent experienced in the decade prior to FISP. This scenario, which serves as the baseline scenario, assumes the country will be unable to maintain the maize-led growth momentum generated under FISP. A second more optimistic scenario assumes a broad-based agricultural growth path as provided for under Malawi's Agricultural Sector-Wide Approach (ASWAp). This policy document outlines Malawi's vision of transforming the agricultural sector from its current overreliance on maize and tobacco to a more diversified one where a broader range of food and export crops are prioritized, and where rapid growth in downstream industrial and service sectors is encouraged through productivity-enhancing investments.

Table 4 Simulated GDP growth paths for selected sector (2005-2010 and 2010-2020)

\begin{tabular}{l|l|l|l|l|l}
\hline & \multicolumn{4}{|l}{} \\
& $\begin{array}{l}\text { Historical maize-led } \\
\text { growth path }\end{array}$ & $\begin{array}{l}\text { Future scenarios } \\
\text { Return to long-run }\end{array}$ & \multicolumn{2}{l}{$\begin{array}{l}\text { Broad-based agricultural } \\
\text { growth }\end{array}$} \\
\cline { 2 - 6 } & $2005-2010$ & $2010-2015$ & $2015-2020$ & $2010-2015$ & $2015-2020$ \\
\hline National GDP & 6.8 & 4.0 & 4.1 & 6.4 & 6.0 \\
\hline Agriculture & 8.5 & 3.3 & 3.4 & 6.5 & 5.1 \\
\hline Cereals & 17.3 & 3.0 & 3.0 & 8.9 & 4.4 \\
\hline Export crops & 4.9 & 4.1 & 4.0 & 5.2 & 7.7 \\
\hline Industry & 5.4 & 4.6 & 4.5 & 6.2 & 6.8 \\
\hline Services & 5.7 & 4.6 & 4.6 & 6.3 & 6.8 \\
\hline
\end{tabular}

Source: Ecker et al. (2012) 
Figure 1 shows changes in poverty and nutrition levels for the historical and future scenarios. Maize is grown extensively by poorer smallholder farmers; hence maize-led growth under FISP contributes to the rapid decline in poverty during 2005-2010. The poverty estimate for 2010 is close to the current official poverty rate of 39\% (see NSO 2012). Under the slower growth scenario no further significant reductions in poverty emerge; in contrast, the broad-based growth scenario is associated with significant further reductions in the poverty rate, which drops below $30 \%$ by 2020 .

The remaining panels in Fig. 1 show changes in calorie and various micronutrient deficiency rates. Historical maize-led growth reduces calorie deficiency from 34.8 to $17.1 \%$. The proportions of people affected by iron, zinc, or folate

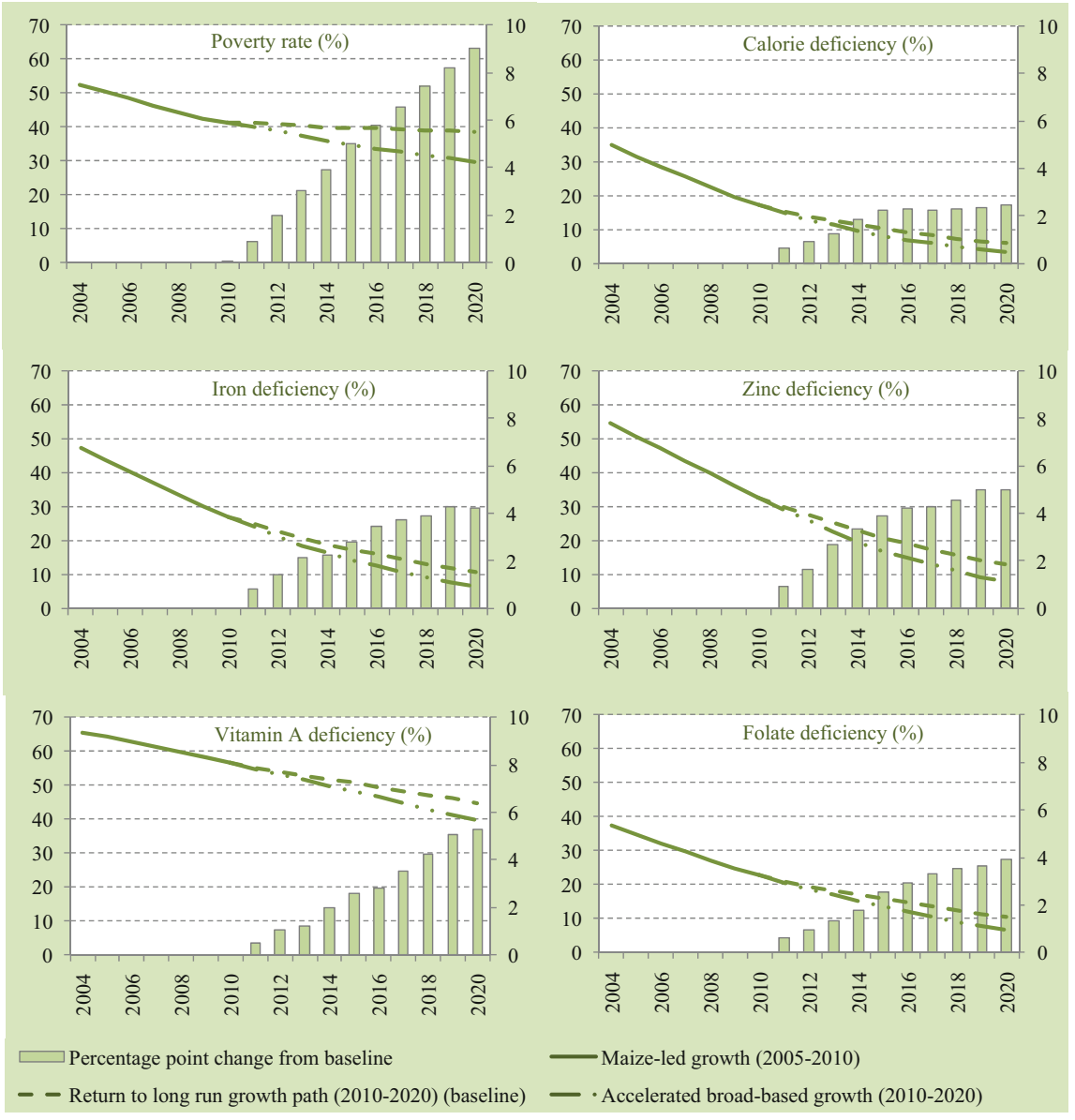

Fig. 1 Poverty and nutritional changes (2005-2020). Source: Based on results in Ecker et al. (2012). Notes: Deficiency rates shown on left axes; percentage point difference between slowgrowth and accelerated growth paths shown on right-hand axes 
deficiencies also decline in both absolute and relative terms (i.e., by more than one-third). Vitamin A deficiency, on the other hand, does not decline as rapidly, which reflects limited quantities of meat, fish, vegetable, and fruit in the average diet. In fact, the absolute number of vitamin A deficient people increases by 400,000 over the period. Thus, FISP, coupled with favorable weather conditions, is likely to be successful in reducing calorie and micronutrient deficiencies in relative and absolute terms, with the exception of vitamin A.

The scenarios for 2010-2020 show continued declines in malnutrition rates, albeit generally at a slower pace compared to the historical period. In the baseline scenario the proportion of calorie deficient people drops to under $10 \%$ after 2015 , while iron, zinc, and folate deficiencies are all estimated to affect less than $15 \%$ of the population by 2020. The absolute number of people deficient in calories and most micronutrients also continues to decrease. Vitamin A deficiency, however, remains a concern, with the absolute number of vitamin A deficient people continuing to rise even though their proportion in the total population drops to well below $50 \%$ by 2020 .

Under the broad-based growth scenario for 2010-2020 nutritional deficiency rates decline considerably faster than in the baseline. Micronutrient deficiencies tend to decline more rapidly than calorie deficiency, at least in percentage point terms. This relates to the high initial incidence of micronutrient deficiencies. From 2015 onwards the rate of decline in calorie deficiency remains stable at around $2 \%$ points below the baseline (see bar chart). In contrast, iron, zinc, and vitamin A deficiencies continue to decline at an increasing rate relative to the baseline, such that by 2020 micronutrient deficiency rates will be about $4-5 \%$ points below the rates in the baseline. By 2020 the number of people deficient in calories, iron, zinc, and folate is more than one-third lower than in the baseline.

\subsubsection{Policy Recommendations}

Ecker et al.'s (2012) analysis shows that economic structure and the characteristics of poor or malnourished people determine whether agricultural or nonagricultural growth is more effective at reducing poverty and malnutrition. In countries such as Malawi where agriculture contributes significantly to national income and where the majority of poor people earn a living from farming, agriculture has an important role to play. Nutrition improves not only for those rural households linked to agriculture; urban households also benefit from agricultural productivity growth and the associated reduction in food prices.

However, cross-country evidence shows how the role of growth shifts during the development process. The comparison between the broad-based growth and baseline scenarios for Malawi confirms this and shows how calorie and micronutrient deficiencies become less responsive to growth as prevalence rates decline, at which point economic diversification is needed to leverage further growth and reductions in malnutrition. 
Ultimately, however, neither agricultural nor nonagricultural growth is sufficient to eliminate poverty, hunger, or micronutrient malnutrition. For example, in the modeled scenario for Malawi, even after a 15-year period of sustained and rapid agriculture-led economic growth, poverty remains close to $30 \%$. This in part reflects the failure of economic growth to trickle down to all the poor and malnourished households; many individuals simply lack access to jobs or markets and hence fail to benefit from growth. As far as nutrition is concerned, the result also reflects lack of access to information and knowledge about proper nutrition, which diminishes the effect of growth-induced changes in household incomes on nutrition. Individual health status and access to healthcare are equally important for nutrition; if growth is not associated with improvements in health service delivery the nutritional effects of growth will be limited, even if higher incomes mean people can better afford health services. This highlights the need for strategic investments and targeted programs that are complementary to growth policies but explicitly aim to improve health and nutrition outcomes and thus strengthen the growth-nutrition linkages.

\section{The Way Forward}

The studies by Pauw and Thurlow (2011) and Ecker et al. (2012) are fairly similar in their approach to measuring the links between (agricultural) growth, poverty, and nutrition. The Tanzania analysis explicitly aimed at identifying agricultural subsectors that are most effective at reducing poverty and hunger, while the Malawi study was more focused on how plausible future economic growth paths might affect nutrition across multiple nutrition indicators. Both studies highlight the importance of the structure of growth in determining the pace of poverty reduction and nutritional improvements, with agricultural growth identified as a particularly important sector given its strong ties with rural poor households. Urban households, however, also benefit from increased availability of cheaper food, which is important for countries such as Tanzania where malnutrition levels are higher in urban areas.

Both approaches have strengths and weaknesses. Missing from both is an assessment of how growth affects the "utilization" dimension of food security and nutrition. For example, more rapid growth may be associated with (or the result of) improved infrastructure and better government service delivery in health and education, which either improves nutrition outcomes or raises the responsiveness of nutrition to higher incomes. Such effects are not easily modeled as endogenous outcomes of growth in standard CGE models; moreover, these models typically assume no changes in household consumption behavior over time and hence also not the way in which food is utilized. Analyses that incorporate the utilization dimensions may therefore require a different modeling framework altogether.

A limitation particular to the Malawi study is that it does not consider how consumption responses in the LES (CGE model) compare with those of the QUAIDS (nutrition module); in fact, even the income elasticities are defined and 
estimated separately. The nutrition module is also not set up to deal with relative price changes (i.e., only real disposable income changes are passed down to the micro-model). Relative prices are therefore implicitly assumed to be unchanged; hence the microsimulation model also disregards changes in the composition of consumption, even if the CGE model's demand system suggests they do change. The model is therefore more suited to analyses of growth-nutrition linkages under a "balanced growth" scenario where relative prices do not fluctuate too much. In essence, therefore, the combined Malawi model framework only considers the demand-side in detail; the supply-side of the nutrition story is reduced to a single measure of income change. In contrast, the Tanzania model explicitly accounts for relative price changes by using the demand system embedded in the CGE model. However, the assumption that all products are gross complements (i.e., cross-price elasticities are negative) is an important limitation of the LES, which means the model is not well suited to analyzing policy shocks leading to large fluctuations in relative prices.

There are, however, some advantages to using a separately-defined demand system for calculating nutrition changes. Whereas demand elasticities in recursive-dynamic CGE models are typically not permitted to change over time, the nutrition demand elasticities in the Malawi microsimulation model are adjusted to account for changes in income levels and the associated behavioral changes (i.e., nutrient demand elasticities are updated to match those of the income cohorts the households move into as their incomes rise). Ecker et al. (2012) are thus able to demonstrate the effect when calorie and micronutrient deficiencies become less responsive to growth as prevalence rates decline over time.

Maize is a widely grown crop in both Tanzania and Malawi, and hence has the potential to significantly contribute to growth and reductions in poverty and calorie deficiency. However, an important question for future research is how a maize-led growth strategy, such as the one followed in recent years in Malawi, might impact on crop diversification and nutrition outcomes across multiple nutrition indicators. The Tanzania study with its narrow focus on calories only cannot answer this question, but neither can the Malawi study, given that the supply of nutrients is not properly accounted for in the microsimulation model (as discussed).

Many of the model limitations can be overcome. Several attempts are underway to introduce a more appropriate demand system into CGE models, specifically one which allows for consumer goods to be treated as genuine substitutes, or a system in which parameters and elasticities can be updated over time to reflect changing consumption behavior (i.e., in recursive-dynamic models). The ultimate aim would be to fully embed a detailed demand system in the CGE model that can be used to evaluate nutrition changes. In the meantime simple model improvements include, in the case of the Malawi model, linking both price and income changes in the CGE model with the microsimulation model, and applying the same set of demand elasticities in both models. The Tanzania model, in turn, can easily be extended to measure changes in the availability of micronutrients as well (data is already available to do so). Ultimately, these studies represent an important step towards better understanding the growth-nutrition linkages. 


\section{References}

Deaton, A. 2010. Understanding the mechanisms of economic development. Journal of Economic Perspectives 24 (3): 3-16.

Dervis, K., J. de Melo, and S. Robinson. 1982. General equilibrium models for development policy. New York: Cambridge University Press.

Diao, X., P. Hazell, and J. Thurlow. 2010. The role of agriculture in African development. World Development 38 (10): 1375-1383.

Diao, X., J. Thurlow, S. Benin, and S. Fan, eds. 2012. Strategies and priorities for African agriculture: Economywide perspectives from country studies. Washington, DC: International Food Policy Research Institute.

Dollar, D., and A. Kraay. 2002. Growth is good for the poor. Journal of Economic Growth 7 (3): 195-225.

Ecker, O., C. Breisinger, and K. Pauw. 2012. Chapter 6. In Reshaping agriculture for nutrition and health, ed. S. Fan and R. Pandya-Lorch. Washington, DC: International Food Policy Research Institute.

Ecker, O., and M. Qaim. 2011. Analyzing nutritional impacts of policies: An empirical analysis in Malawi. World Development 39 (3): 412-428.

Heidhues, F., A. Atsain, N. Hezron, M. Padilla, G. Ghersi, and J. Le Vallée. 2004. Development strategies and food and nutrition security in Africa. An assessment. IFPRI 2020 Discussion Paper, 38. Washington, DC: International Food Policy Research Institute.

Löfgren, H., S. Robinson, and R. Harris. 2002. A standard computable general equilibrium (CGE) model in GAMS. Washington, DC: International Food Policy Research Institute.

Lukmanji, Z., E. Hertzmark, N. Mlingi, V. Assey, G. Ndossi, and W. Fawzi. 2008. Tanzania food composition tables. Dar es Salaam, Tanzania; Boston, MA, Muhimbili University of Health and Allied Sciences (MUHAS); Tanzania Food and Nutrition Centre (TFNC); Harvard School of Public Health (HSPH).

Mellor, J.W. 1999. Faster, more equitable growth: The relation between growth in agriculture and poverty reduction. Cambridge, MA: Harvard University Press.

MOFEA (Ministry of Finance and Economic Affairs). 2008. The economic survey 2007. Dar es Salaam: Ministry of Finance and Economic Affairs.

NBS (National Bureau of Statistics). 2002. Tanzania: Household budget survey 2000/01. Dar es Salaam: National Bureau of Statistics.

\section{Statistics.}

NSO (National Statistical Office). 2012. Integrated household survey 2010/11. Malawi: National Statistical Office.

Pauw, K., and J. Thurlow. 2011. Agricultural growth, poverty, and nutrition in Tanzania. Food Policy 36 (6): 795-804.

- 2012. The role of agricultural growth in reducing poverty and hunger: The case of Tanzania. In Reshaping agriculture for nutrition and health, ed. S. Fan and R. PandyaLorch, 55-64. Washington, DC: International Food Policy Research Institute. doi:10.2499/ 9780896296732.

Ravallion, M., and G. Datt. 1996. How important to India's poor is the sectoral composition of economic growth? The World Bank Economic Review 10 (1): 1-26.

Timmer, C.P. 2000. The macro dimensions of food security: Economic growth, equitable distribution, and food price stability. Food Policy 25 (3): 283-295.

UNU, WHO, and FAO (United Nations University, World Health Organization, and Food and Agriculture Organization of the United Nations). 2004. Human energy requirements: Report of a joint FAO/WHO/UNU expert consultation. Rome, October 17-24, 2001. FAO Food aned Nutrition Technical Report Series 1. Rome: FAO.

Valdés, A., and W. Foster. 2010. Reflections on the role of agriculture in pro-poor growth. World Development 38 (10): 1362-1374. 
Karl Pauw is the Regional Coordinator for the Monitoring and Analyzing Food and Agricultural Policies (MAFAP) program of the United Nations Food and Agriculture Organization (FAO), based in Addis Ababa, Ethiopia. At the time of writing his respective contributions in this book he was a Research Fellow at the International Food Policy Research Institute (IFPRI) and manager of IFPRI's Malawi country program in Lilongwe. He holds a PhD in development economics from the University of Cape Town, South Africa, and his research interests include: development and agricultural policy analysis; microeconomic analyses of labor markets, poverty, welfare outcomes, and nutrition; and policy impact analysis using computable general equilibrium and microsimulation models.

James Thurlow is a Senior Research Fellow in the Development Strategies and Governance Division at the International Food Policy Research Institute in Washington DC. James' research focuses on the economy-wide interactions between policies and economic growth, poverty and inequality. James has published more than 80 articles and books that evaluate the contribution of public investments and policies to rural and national development in Africa and Asia.

Olivier Ecker is a Research Fellow in the Development Strategy and Governance Division of the International Food Policy Research Institute (IFPRI), Washington, DC. His research focuses on development policies and programs for poverty reduction and food and nutrition security in Africa and the Middle East.

Open Access This chapter is licensed under the terms of the Creative Commons Attribution 4.0 International License (http://creativecommons.org/licenses/by/4.0/), which permits use, sharing, adaptation, distribution and reproduction in any medium or format, as long as you give appropriate credit to the original author(s) and the source, provide a link to the Creative Commons license and indicate if changes were made.

The images or other third party material in this chapter are included in the chapter's Creative Commons license, unless indicated otherwise in a credit line to the material. If material is not included in the chapter's Creative Commons license and your intended use is not permitted by statutory regulation or exceeds the permitted use, you will need to obtain permission directly from the copyright holder.

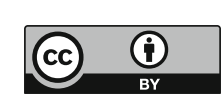

